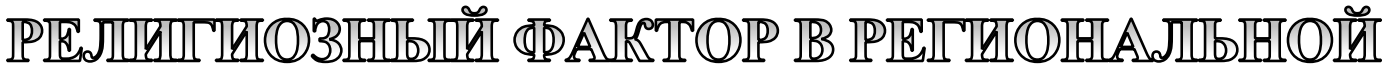

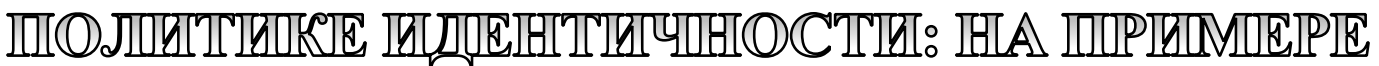

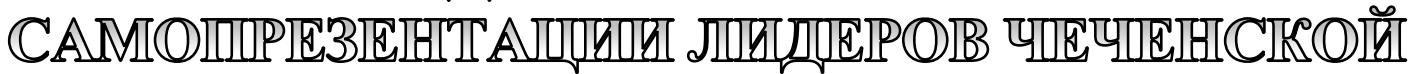

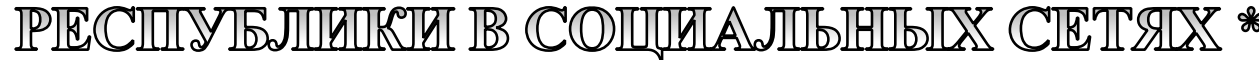

А.В. Михалева, Пермский федеральный исследовательский центр УрО РАН

Современное сетевое общество с исключительной ролью интернет-коммуникаций качественно меняет все сореры жизнедеятельности, открывая через виртуальные каналы дополнительные возможности для манипуляции общественным сознанием. В рамках настоящей статьи предлагается остановиться на религиозном аспекте самопрезентации руководства Чеченской республики в социальных сетях и рассмотреть, каким образом и в каком масштабе актуализируется «религиозное» на интернет-страницах политической и религиозной элиты республики. Социополитический анализ взглядов и установок элитных групп позволяет определить векторы развития регионального сообщества и спрогнозировать назревающие проблемы, основные характеристики и элементы которых находят отражение на страницах социальных сетей. В статье представлены результаты социологического исследования интернет-активности чеченской элиты на страницах в ВКонтакте, Инстаграм и Телеграм.

Исследование строилось на сетевом анализе - бесконтактном методе цифровой социологии - с учетом нормативного, визуального и содержательного аспектов презентации изучаемых объектов. В качестве последних были взяты политические и религиозные лидеры Чечни: Глава ЧР Рамзан Кадыров, Председатель правительства ЧР Муслим Хучиев, а также советник по религиозным вопросам при главе ЧР Адам Шахидов и муфтий ЧР Салах Межиев.

Проведен анализ их публикационной активности и текстового содержания комментариев, что позволило определить основные стратегии включения религиозного ресурса в региональную политику идентичности. В результате исследования выявлена высокая значимость религиозного ресурса для идеологического обоснования политических действий региональной элиты. При этом ссылка на религиозный контекст носит инструменталистский характер и определяется политической конъюнктурой. В заключении озвучены наиболее проблемные нюансы религиозного дискурса чеченских лидеров.

Ключевые слова: ислам, институционализация, политика идентичности, сочиальные сети, Кадыров, Хучиев, Шахидов, Межиев.

\footnotetext{
* Статья подготовлена при финансовой поддержке РФФИ, проект № 19-01100810 А «Институционализация этничности в политике идентичности российских республик: комплексный сравнительный анализ».
} 


\section{Введение}

Современное сетевое общество с исключительной ролью интернет-коммуникаций качественно меняет все сферы жизнедеятельности, открывая через виртуальные каналы дополнительные возможности для манипуляции общественным сознанием. Все большую убедительность приобретает утверждение испанского социолога М. Кастельса, что сегодня «... власть базируется на контроле за коммуникацией и информацией, будь то макровласть государства и медиакорпораций или микровласть организации любого рода» $[20,22]$. Именно коммуникация становится эпицентром битвы за ценностное нормирование общественной жизни. При этом «во многих случаях обладатели власти сами являются сетями. Не абстрактными, лишенными сознания сетями, не автоматами - это люди, объединяющиеся вокруг своих проектов и интересов. При этом они не являются единичными акторами (индивидом, группой, классом, религиозным или политическим лидером) - пока исполнение власти в сетевом обществе требует сложного набора совместной деятельности, выходящей за рамки союзов - но становящейся новой формой субъекта, близкой к тому, что Бруно Латур прекрасно определил как «актор-сеть» $[22,64]$. В таком обществе интернет и социальные сети превращается в важный ресурс доминирования и власти, через которые идет моделирование политического имиджа, обеспечивается политическая и социальная мобилизация и интеграция пользователей.

В рамках настоящей статьи предлагается остановиться на религиозном аспекте самопрезентации руководства Чеченской Республики в социальных сетях и посмотреть, каким образом и в каком масштабе актуализируется «религиозное» на интернет-страницах политической и религиозной элиты субъекта Российской Федерации.

Актуальность изучения взглядов руководства республики обусловлена тем, что именно оно задает тон основных измене- ний в регионе. Следовательно, социополитический анализ ориентаций и установок элитных групп позволяет определить векторы развития регионального сообщества и спрогнозировать назревающие проблемы, основные характеристики и элементы которых находят отражение в социальных сетях. Пример Чеченской Республики показателен и интересен с точки зрения особых условий автономности политического режима, с одной стороны, и крепких религиозных традиций - с другой, что позволяет сформировать специфическую модель государственно-религиозного дуализма.

\section{Теоретические рамки исследования}

Изучение общественно-политических взглядов республиканской элиты базировалось на бесконтактном методе цифровой социологии - сетевом анализе, при котором социальные сети выступают в качестве основного источника информации. При анализе интернет-коммуникаций учитывались нормативный, визуальный и содержательный аспекты презентации элиты.

Для анализа были взяты интернетстраницы основных политических и религиозных лидеров ЧР: Главы ЧР Рамзана Кадырова, Председателя правительства ЧР Муслима Хучиева, а также советника по религиозным вопросам при Главе ЧР Адама Шахидова и муфтия ЧР Салаха Межиева. Отбор материала для анализа осуществлялся по многоступенчатой выборке. На первоначальной стадии выявлялись все социальные сети самопрезентации указанных фигур. На втором этапе учитывалась активность указанных акторов на конкретных интернет-страницах, в результате чего были отобраны наиболее востребованные ресурсы с частым обновлением новостной ленты. На третьей стадии был осуществлен текстовый и визуальный анализ отобранных страниц. Субъектная принадлежность интернетстраниц устанавливалась с помощью прямых ссылок на ресурсы политической и религиозной элиты ЧР, а также через прикрепленные ссылки на ресурсах коллег. 
В итоге для анализа отобраны четыре интернет-страницы (Р. Кадырова в ВКонтакте, М. Хучиева и А. Шахидова в Инстаграм, С. Межиева в Телеграм) и проанализированы 2700 сообщений в период с 01.01.2020 по 30.06.2020 г.

\section{Результаты исследования}

Результаты статистического анализа. Количественный анализ интернет-активности лидеров Чечни позволяет оценить реальный уровень их публикационной активности, актуальную повестку дня, а также отследить динамику приоритетных тематических направлений. На выбранный для исследования период пришелся взрывной рост заболеваемости коронавирусом, что оказало влияние на тематику публикаций и на поднимаемые в них проблемы. Поэтому при анализе дополнительно учитывались показатели интернет-активности до введения режима самоизоляции в регионах (январь-март) и после (апрель-июнь).

Максимальное количество публикаций за указанный период разместили на своих страницах муфтий ЧР С. Межиев (760), советник Главы Республики по религиозным вопросам А. Шахидов (740), вслед за ними с небольшим разрывом следует Р. Кадыров (713). Меньше всего публикаций за тот же период оставил Председатель правительства ЧР М. Хучиев (487 сообщений). С. Межиев, А. Шахидов и Р. Кадыров с незначительным разрывом лидируют по ежедневной публикационной активности $(4,4 ; 4,2$ и 4,01 сообщения в сутки). Самые низкие параметры данного показателя у председателя правительства М. Хучиева $(2,8)$. Текстовый анализ сообщений свидетельствует о том, что многие сообщения на странице С. Межиева повествуют о нем в третьем лице, что позволяет говорить об опосредованности данного источника.

Тематический анализ сообщений не выдал неожиданного результата в отношении А. Шахидова и С. Межиева, поскольку очевиден приоритет их профессиональной проблематики в комментари- ях. Аналогичным образом повестка дня М. Хучиева в большинстве своем определяется текущими политическими вопросами. Комментарии А. Шахидова и С. Межиева в основном носят религиозный характер с той разницей, что А. Шахидов чаще затрагивает вопросы религиозно-идеологического содержания, в то время как С. Межиев, как правило, освещает конкретную ритуальную практику.

Наибольший интерес представляет тематический анализ комментариев Главы ЧР, в которых спектр затронутых тем оказался более разнообразным в силу специфики профессиональной деятельности. Если на странице Р. Кадырова до активных событий с коронавирусом среди сообщений лидировали различного рода поздравления (36,3\% от всех сообщений за этот период), комментарии на политические $(10 \%), \quad$ спортивные $(9,6 \%)$ темы, вопросы здравоохранения $(7,9 \%)$ и религиозные сюжеты (7,3\%), то в апреле-июне мы наблюдаем смену тематических приоритетов: на первое место вышли вопросы памяти Ахмата Кадырова (38\%), поздравительный дискурс (16,3\%), здравоохранение $(14,4 \%)$, благотворительность $(11,7 \%)$. Религиозная тематика также осталась на пятой позиции $(6,8 \%)$, в то время как политические вопросы и спорт немного «просели». Повышенное внимание к фигуpe первого президента ЧР, очевидно, объясняется тем, что на этот период приходится годовщина его гибели.

Отдельно следует обратить внимание на дублирование тем и постов на отобранных для анализа страницах, например, в вопросах братства, уникальности чеченского ислама, религиозности семьи Кадыровых и т.д.

Доля сообщений с религиозной тематикой у Р. Кадырова составляет $8 \%$. Помимо этого, $\quad 17 \%$ нерелигиозных сообщений отмечены религиозными формулами («Аллаху Акбар!», «Хвала Аллаху» и др.) Очевидно, что религиозная тематика остается определяющей для личных страниц С. Межиева и С. Шахидова в социальных сетях. 
Результаты визуального анализа. Как показывают результаты визуального анализа собранных данных, Глава Чечни активно демонстрирует свою религиозность в общественно-политическом дискурсе. Вместе с приближенными он регулярно посещает пятничные рузба-намазы, что подтверждают не только фотоснимки в кругу друзей с распростертыми ладонями во время намаза, но и еженедельные отчеты о посещении мечети на страницах в социальных сетях. Например, за январь 2020 г. Р. Кадыров оставил на своей странице пять сообщений о посещении джума-намаза. На обязательность посещения пятничных намазов для мужчины постоянно указывает на своей странице в Телеграм и муфтий ЧР С. Межиев [31].

Визуальный анализ религиозной символики на одежде политической элиты ЧР также свидетельствует об активном позиционировании ее религиозной идентичности. Р. Кадыров регулярно появляется на публике в мюридских костюмах с полумесяцем и звездой на груди, на которых также присутствует маркировка Дома моды «Firdaws». Данный бренд использует арабское наименование «Высочайшего из садов в раю» «как место удивительной красоты и гармонии» [33]. В костюмах этого же Дома моды обычно проводит свои рабочие совещания и председатель правительства ЧР М. Хучиев.

Помимо мюридских костюмов с религиозной символикой, политическая элита Чечни охотно позирует в ихрамах (специальная накидка для паломников) [63]. 26 февраля 2020 г. на странице в Инстаграм А. Шахидов разместил свою фотографию с сидящими рядом М. Даудовым, С. Межиевым, А. Делимхановым в ихрамах и с четками (субха) в руках. Фотография в аналогичном облачении размещена на странице Р. Кадырова от 19 мая этого года под постом о заседании оперативного штаба по борьбе с коронавирусом и просьбой отметить Ураза-Байрам в домашних условиях [11].

В объективы фотокамер очень часто попадают совместные намазы Р. Кадыро- ва с близкими друзьями. 19 июня этого года после паломничества по зияратам Р. Кадыров в сопровождении муфтия ЧР С. Межиева, депутата Госдумы РФ А. Делимханова, Председателя Парламента ЧР М. Даудова, советника Главы ЧР А. Шахидова совершили вечерний намаз в мечети в городе Шали. Во время намаза по правую руку от молящегося Р. Кадырова расположился А. Демлиханов, по левую - С. Межиев [12].

На личных страницах политической и религиозной элиты ЧР появляются не только их снимки во время коллективных намазов, но и, например, видеорепортажи коллективной молитвы сотрудников СОБР «Терек» Управления Росгвардии по Чеченской Республике [54].

О роли религии в чеченском обществе и региональной политике позволяют судить церемониальные нюансы организации совещаний. Очень часто на общих правительственных совещаниях присутствует муфтий ЧР С. Межиев, который располагается в непосредственной близости от Главы Республики. 17 марта 2020 г. Р. Кадыров выложил пост о прошедшем совещании по проблемам и перспективам агропромышленного комплекса. В сообщении также указано, что в заседании, помимо представителей исполнительной и законодательной власти, силового блока, приняло участие и духовенство. Несмотря на отсутствие религиозной тематики в рабочей повестке дня, тем не менее отмечено присутствие «дорогого БРАТА» муфтия ЧР С. Межиева [9]. Несколькими днями ранее, 12 марта 2020 г., Кадыров выложил видео совещания о деятельности учрежденных им полгода назад восьми территориальных секторов [2] для контроля за решением вопросов социально-экономического развития, на котором муфтий ЧР расположился по правую руку от Главы Республики [8]. Подобные комментарии и снимки с совещаний у Главы Республики отсутствуют на личной странице С. Межиева в Телеграм. 
Визуальную картинку чеченского ислама дополняет образ идеальной исламской семьи в лице семьи Кадыровых, которая отличается «высоким нравом» и «их непрерывной борьбой за ИСЛАМ на мировом уровне» [39], в которой чтутся и соблюдаются все исламские традиции и «сияет свет Корана». Здесь дети с малых лет изучают Коран, цитируют его аяты, о чем выкладываются регулярные видеосюжеты [64], которые охотно воспроизводят на своих страницах А.Шахидов и М. Хучиев, но полностью отсутствуют на странице С. Межиева в Телеграм.

\section{Содержательный анализ личных страниц}

Возможности интернет-ресурсов в современном мире вполне осознаются руководством Чечни. А. Шахидов на своей странице открыто заявляет, что «социальные сети - один из главных ресурсов для получения и обмена информации. ... Активным пользователем социальных сетей является и мой ДОРОГОЙ БРАТ, ГЛАВА ЧР РАМЗАН-ХАДЖИ КАДЫРОВ ${ }^{1}$ [50].

\section{Исламская идентичность}

Несмотря на то что Глава Республики не скрывает свою религиозную идентичность и открыто ее демонстрирует, он избегает «Я-характеристик» исламской идентичности. Чаще всего свою исламскую идентичность Р.Кадыров выражает через фразу «мы мусульмане...». Однако, как показывает текстовый анализ, его окружение не скупится на яркие сравнения и достаточно изобретательно в своей креативности. Наибольшее усердие в этом вопросе проявляет советник по религиозным делам главы ЧР А. Шахидов. C его страницы в инстаграм не сходят такие определения, как «ЗАЩИТНИК ПРЕЧИСТОЙ СУННЫ», «СЛУЖИТЕЛЬ СВЯЩЕННОГО КОРАНА» [58], «наш Лев» [57], «праведный правитель» [69], «ГЕРОЙ ИСЛАМА, ХРАНИТЕЛЬ СВЯЩЕННЫХ РЕЛИКВИЙ СЫН
ШАХИДА» [38]. А. Шахидов сравнивает Рамзана с Пророком в силе веры [70], называя его «защитником Пророка Мухаммеда» [68], тем самым доводит восхваление своего героя до обожествления его персоны. Председатель правительства ЧР М. Хучиев на этом фоне смотрится куда скромнее и ограничивается простым обращением «Дорогой Брат» [36]. Такую же сдержанную позицию занимает и муфтий ЧР С. Межиев, который не так часто в своих постах упоминает Главу Республики и использует применительно к нему такие обращения, как «национальный лидер» [25], за редким исключением - «ЗАЩИТНИК ПРЕЧИСТОЙ СУННЫ» [26].

Помимо активной визуальной презентации своих религиозных убеждений, о чем говорилось выше, в апреле 2020 г. свою бритую голову Р. Кадыров откомментировал в религиозном контексте как следование Сунне [16]. На странице в соцсетях он не избегает и советов с религиозным содержанием. Например, в Ночь предопределения (Лайлат аль-Кадр) в мае 2020 г. он призвал «оживить эту ночь чтением Корана» [14]. В своих выступлениях и комментариях Р. Кадыров не забывает напоминать землякам о регулярности религиозной практики «для получения милости Творца» [47].

Не только Глава республики позиционирует себя в качестве активно практикующего мусульманина, но и республика позиционируется политической и религиозной элитой как исламская. Помощник Главы Республики по религиозным вопросам А. Шахидов размещает на своей странице в Инстаграм репост о «возвышенном знамени ислама» в республике: «Рамзан-Хаджи Кадыров показал, что Чеченская Республика, которую преступники хотели связать в представлении людей с терроризмом, может не просто придерживаться созидательного курса и пути мира, но ещё и возвысить знамя Ислама. Это знамя

\footnotetext{
1 Здесь и далее по тексту сохранена орфография и пунктуация автора цитаты.
} 
оказалось возвышенным настолько, что теперь его видно со всех уголков Земли и на него равняются остальные» [48].

\section{О чеченском исламе}

Особенностью традиционного ислама в Чечне является то, что здесь он представлен в форме суфизма накшбандийского и кадирийского тарикатов. Политическое и духовное руководство современной Чечни является приверженцами именно кадирийского тариката вирда шейха Кунта-Хаджи [21]. Вследствие этого день Кунта-Хаджи Кишиева (3 января) включен в пантеон официальных государственных праздников республики. В своих поздравлениях по поводу празднования этой даты Р. Кадыров не скрывает семейной традиции поклонения шейху [3]. Он вместе с приближенными регулярно посещает зияраты, связанные с историей этого шейха [13]. Именно суфийский характер ислама и его ритуальные практики часто становятся объектом критики из исламского мира.

Чтобы избежать обвинений со стороны зарубежных мусульман и исламских авторитетов в незаконности проповедуемого в Чечне ислама, А. Шахидов часто обращается к внешним исламским авторитетам и с их помощью легитимирует религиозные процессы в Чечне, в частности, законность зикра кадырийского тариката Кунта-Хаджи [41].

В спорах о специфике чеченского ислама А. Шахидов легко переходит на сомнительные методы, используя некорректные утверждения: «У кого нет вирда - тот обезьяна!!!» [62]. В комментариях к посту читатели справедливо задаются вопросом, как например, пользователь «_abu_bakr_8»: «Путин тоже тогда объезана, так как у него тоже нету вирда». Подобные вопросы остаются без ответа автора страницы.

Содержательный анализ сообщений позволяет сделать вывод о том, что теоретические вопросы вероучения ислама на страницах Главы Республики и председателя правительства не затрагиваются, это вполне объяснимо с точки зрения их ста- тусной роли. Однако в сообщениях советника Главы Чечни по религиозным делам А. Шахидова и муфтия ЧР С. Межиева ситуация совсем иная: здесь часто обсуждаются теологические нюансы вероучения. Так, муфтий республики на своей личной странице в Телеграм очень активно противостоит своему главному врагу «ваххабитам». Он парирует обвинения в адрес чеченского ислама относительно почитания устазов, допустимости тарикатов, следования не только Корану, но и мазхабам в качестве источника веры.

Взгляды ваххабитов, по мнению С. Межиева, противоречат данным современной науки [29], а также «истинному Исламу» [27]. Аналогичная мысль о законности мнения чеченских улемов тиражируется на странице А. Шахидова. Он публикует видеообращение Аймана Рушди Сувейда исламского богослова из Сирии - к мусульманам республики: «Сыны Чечни ... слушайте своих алимов» [51]. Ставка на собственных религиозных авторитетов позволяет избежать критики извне.

В то же время все чаще с помощью внешних исламских игроков подчеркивается исключительность чеченской уммы. На странице А. Шахидова приведены слова некого Ясира Аль-Хусейна: «Не ограничивайте своё мышление границами ЧЕЧЕНСКОЙ РЕСПУБЛИКИ, a, напротив, помните, что вы - это часть общины, которая является лучшей из всех общин, когда-либо выведенных для людей, если АЛЛАХ дарует ей такого предводителя как РАМЗАН» [45].

Среди этих же методов воздействия используется ссылка на мнение арабоязычных СМИ об исключительности исламской уммы Чечни [65]. В таком контексте, как правило, поддерживается смысловая коннотация «Чечня-народГлава» без ссылок на Россию, а гиперболы как метод манипулирования сознанием рассчитаны в основном на внутреннего чеченского потребителя.

Идея исключительности чеченской уммы закрепляется также ссылкой на еe особую миссионерскую роль, правда, 
подается это вполне искусно через исторический контекст: «Кто поможет исламу, если не мы?!» [53]. Значение категории «мы» в применительно к нашему дню из фразы египетского султана Сайф идДина Кутуза не уточняется, но учитывая, аудиторию читателей, ответ очевиден.

На своих личных страницах в социальных сетях чеченская элита пытается придать исламское звучание практически всем темам, правда, не всегда удачно. Одним из ярких примеров искажения фактов стал видеосюжет о Зомби, размещенном на странице А. Шахидова [55], в котором утверждается, что «правитель мусульман Зомби, герой из героев мусульманского государства Бразилии» «объявил об установлении государства ислама в Бразилии». А в качестве главной причины падения созданного им образования называется ненависть христиан и крестовые походы. Речь, видимо, идет о Зумби и жителях республики Палмарис (1630-1694), которые исповедовали афрохристианский синкретический культ, а само государство потерпело крах в первую очередь в силу политических и экономических причин. Очевидно, общая ссылка на Бразилию без уточнения региона или ее области вводит в дополнительное заблуждение, поскольку республика Палмарис занимала лишь $0,3 \%$ от общей площади государства. Именно такие методы (замалчивание деталей, гипертрофированный акцент на исламе, подмена и передергивание понятий и т.д.) наиболее часто используются в текстах советника Главы Республики по религиозным вопросам.

\section{Связь этнического и религиозного}

В изложении религиозных деятелей Чечни этническое и религиозное прочно связано в сознании чеченцев, поскольку любовь к Родине, по мнению А. Шахидова, «связана с ИСЛАМОМ» [42]. Эта связь обнаруживается, по мнению советника, в самые тягостные моменты истории, например, в период депортации чеченского народа. Как подчеркивает
А. Шахидов, именно религия стала основным инструментом спасения [60]. В то же время муфтий ЧР С. Межиев в своем выступлении по случаю депортации чеченского народа умолчал о религии как факторе спасения и лишь попросил Аллаха о прощении за погибших [30]. Спустя несколько месяцев о религиозности чеченцев еще более конкретно выразился сам А.Шахидов: «Ислам притягивает чеченцев, как магнит притягивает железные стружки. Чеченец и мусульманин - можно сказать, одно и то же» [59].

Тесная связь этнического и религиозного в самосознании чеченцев подтверждается результатами социологического исследования, проведенного в мае 2018 г. в ЧР [34]. Однако природа высокой религиозности среди чеченцев объясняется не только историческими традициями. Вполне можно согласиться с выводами исследования, проведенного в 2016-2017 гг. в городах Чечни (Грозный, Гудермес) и Дагестана (Махачкала, Каспийск), о том, что высокая религиозность в этой сфере поддерживается государством и «является фактором социального тестировании и определяет статус личности в тухуме, тейпе, (роду), семье и джамаате» [1].

\section{Ислам и братство}

Не секрет, что сегодняшнее окружение Главы ЧР выстраивается по принципу «братства». Эта тема часто поднимается на личной странице Р. Кадырова ВКонтакте $\quad(10.06 .2020, \quad 31.05 .2020$, $30,05.2020,28.05 .2020,29.03 .2020$ и т.д.) и его приближенных. Понимание братства четко прописывается в сообщениях Р. Кадырова и несет в себе, в том числе, и религиозный подтекст: «Эти Братство и Дружба для нас незыблемы и священны, ибо выстроены на Вере во ВСЕВЫШНЕГО и на горячей Любви к своему Народу... Так было, так есть, так будет во все времена! АЛЛАХУ АКБАР! АХМАТ-СИЛА!!!» [7]. Это братство часто визуализируется как на странице самого Рамзана, так и на страницах его сподвижников. 
Более конкретное понимание братства на странице в Инстаграм дал А. Шахидов: фотография сидящих за столом Р. Кадырова, А. Шахидова и С. Межиева обрамлена надписью «Братство ради Аллаха нерушимо» [69]. В комментарии к фотографии он приводит слова имама аль-Хасана аль-Басри: «Наши БРАТЬЯ по вере порой любимее для нас, чем даже родственники, потому что братья по вере напоминают нам о вечной жизни, а родственники иной раз лишь о мирской» [67]. В то же время тематика дружбы и братства крайне редко встречается на личной странице С. Межиева в Телеграм. Судя по визуальному ряду, представленному на личных страницах руководства Чечни, подобные встречи в кругу друзей и братьев происходят регулярно и с большим удовольствием.

Обычно среди «братьев» можно видеть А. Демлиханова, М. Даудова, А. Шахидова, С. Межиева и других приближенных к Р.Кадырову лиц. В таком составе посещаются пятничные рузбы, кладбища и зияраты [5]. Встреча с братьями используется, в том числе, и для «поминания [Аллаха - прим. авт.], чтения мавлидов и коллективных богослужений!» [6]. В сообщении от 28 мая этого года и рассуждениях о дружбе в исламе Р.Кадыров добавляет: «Пусть Аллах не лишит нас дружбы с праведными людьми и пребывания с лучшими из них» [17].

Обращаясь к значению термина «братства» на странице Главы Республики становится очевидным, что, с одной стороны, его трактовка вполне конкретна, с другой - его значение легко варьируется в зависимости от актуального момента. В комментарии об А. Демлиханове Р. Кадыров раскрывает братскую любовь через самопожертвование близких, «готовых, не моргнув глазом, отдать за тебя свою жизнь»; «не обязательно единокровные, но именно кровь, пот и слёзы скрепили наше железное братство десятками лет... АДАМ один из них» [19]. Причем в этом же сообщении Рамзан постоянно жонглирует понятиями «друг» и «брат» применительно к А. Демлиханову. И хотя при- сутствует оговорка о том, что друзей может быть много, а, следовательно, братьев меньше, но в конце все сводится к «ДРУЖЕСКОЙ И БРАТСКОЙ ЛЮБВИ».

С другой стороны, к теме братства в интерпретации чеченского руководства не следует относиться исключительно с точки зрения самопожертвования, «пота и крови», поскольку иногда братские отношения конструируются им на религиозном и историческом контексте без прямых контактов. Так, в сообщениях Р. Кадырова «братским» называется турецкий народ, а «братьями» - любимые актеры из турецкого сериала «Основание Осман» (Турция, 2017 г.) Мухаммеда Эмре Учтэпэ, Бурака Озчивита [20]. Очевидно, тема братства в устах Р. Кадырова актуализируется и популяризируется в зависимости от запросов и обстоятельств и, бесспорно, наполнена сильным эмоциональным содержанием.

\section{«Сильный» ислам}

Одной из приоритетных тем интернет-сообщений руководства ЧР стал тезис о «сильном» исламе в плане физической подготовки его последователей. Сам Глава Чечни охотно занимается спортом и со своей страницы ВКонтакте регулярно пропагандирует здоровый образ жизни. 19 января 2020 этого года он обратился к молодому поколению: «Мой юный друг, запомни! Лишь в трёх местах находим мы истинное упокоение и гармонию с ВСЕВЫШНИМ и с собой: в Доме АЛЛАХа, в кругу семьи и, конечно же, в спортивном зале... Читайте Коран, будьте добры к родным и занимайтесь спортом! АХМАТ-СИЛА!!! АЛЛАХУ АКБАР!!!» [10].

Этот призыв несколькими днями позже поддержал и его советник А. Шахидов, цитируя в своем видеоролике известную фразу из хадиса: «Сильный верующий лучше слабого» [61]. Шахидов неоднократно подчеркивает трактовку этого хадиса в духе имама аль-Куртуби, где делается акцент на «...сильного телом и духом человека с твёрдой решитель- 
ностью, способного выполнять обязательные поклонения как ХАДЖ, ПОСТ, повеление совершать хорошее и остальное, благодаря чему сохраняется религия» [40].

В своем наставлении относительно воспитания детей Р.Кадыров подчеркивает: «В современном мире мало уделяется внимания приучению детей и подростков с раннего возраста обращению с оружием, а также вести из него меткую стрельбу» [4]. Говоря о своих сыновьях, Р. Кадыров делится собственным опытом воспитания: «С каждой тренировкой они увереннее держат в руках оружие, а выстрелы становятся точнее» [18].

В вышеприведенных комментариях Р. Кадырова не было прямой привязки к исламу, однако, как показывает контент публикаций, настойчивые требования о владении оружием периодически приобретают религиозное звучание. На своей странице в Инстаграм от 14 марта этого года А. Шахидова разместил видео, демонстрирующее меткую стрельбу по бутылкам, снабдив его своим комментарием «АХМАТСИЛА АЛЛАХУ АКБАР!!!» [46].

В отличие от приведенного дискурса комментарии муфтия ЧР С. Межиева в вопросе воспитания подрастающего поколения выглядят более сдержанными и лаконичными: «Самое ценное что может передать отец своему ребёнку, обучить религии» [28]. За весь период анализа на его странице в Телеграм не найдено ни одного сообщения об оружии, стрельбе и тренировках.

Наоборот, А. Шахидовым активно военизируется любая деятельность на благо республики, в том числе и обычные будни воспринимаются как война: «Когда каждый из нас не работник, не сотрудник, а воин - воин созидания и милости, воин переживания и стремления помочь своему народу...» [56]. Военные структуры, напри- мер, полк ППСП им. Героя России А.А. Кадырова, рассматриваются как воины на пути Ислама, исполнители джихада [43] ${ }^{2}$.

Периодически сами лидеры Чечни в шутливой форме разыгрывают взаимосвязь ислама и холодного оружия. Так, 28 мая 2020 г. на своей странице А. Шахидов разместил свой снимок с окровавленными руками и ножом в присутствии Р. Кадырова, снабдив его комментарием: «Кто не понял тот поймёт. АХМАТСИЛА АЛЛАХУ АКБАР!!!»[66]. Очевидно, речь идет о ритуале жертвоприношения во время празднования Уразы, однако смакование не совсем эстетичных моментов со стороны обремененных статусом руководителей не вполне понятно.

Из взятых для анализа сообщений становится вполне понятно, кому адресована демонстрация силы и против кого будет развязан джихад. Например, Р. Кадыров безапелляционно заявляет: «А кто является нашим врагом?! Посмотрите вон на ту мечеть или любую другую, без разницы, если нам скажут закрыть ее, то клянусь Аллахом, кто не будет сражаться с теми, кто скажет это, до последней капли крови, да унизит его Аллах в этой жизни и в Вечной!» [37]. К «очищению общества от врагов ислама» призвал в своем новогоднем обращении и муфтий ЧР С. Межиев [24]. В таких сообщениях невозможно игнорировать готовность заявителей в объявлении джихада.

Помимо культа оружия и силы, в интернет-комментариях руководителей ЧР, пожалуй, больше настораживает другой момент, а именно отсутствие в их сообщениях привязки к правовому контексту и легитимности подобных действий. Ярким примером таких интерпретаций силы могут стать последние события во французском Дижоне, где чеченская диаспора с бейсбольными битами, металлическими прутами и ножа-

\footnotetext{
2 Полк полиции специального назначения им. Героя России А.А. Кадырова МВД по Чеченской республике был сформирован в 2004 году по инициативе первого Президента Чечни Ахмата Кадырова. В настоящее время его возглавляет Замид Чалаев. За структурой закрепилось неофициальное название «кадыровского спецназа»
} 
ми в руках дала отпор африканским наркодилерам [23, 35]. Открытая реакция руководства Чечни на события в Дижоне 10-17.06.2020 г. последовала с заметной задержкой. Лишь 22 июня А.Шахидов опубликовал пост на странице в Инстаграм, в котором одобрил и поддержал действия чеченцев [61]. При этом силовые методы такого сдерживания отнюдь не подвергаются сомнению.

\section{Ислам и политика}

Анализ текстовых сообщений на личных страницах лидеров Чечни в социальных сетях также позволяет проследить непосредственную связь ислама и политики. Многие внутриполитические вопросы решаются через призму ислама. Из актуальных примеров наглядно обращение Р.Кадырова к населению республики накануне голосования по поправкам в Конституцию России. Он призывает «быть полезными своей стране», в которой свободно исповедуется ислам [15]. Через девять дней перед чеченским народом выступил муфтий республики С.Межиев и отметил огромную важность участия в голосовании по поправкам к Конституции, которая содержит в том числе право на свободу вероисповедания [32].

Кроме того, вопросы, которые, казалось бы, не имеют прямого отношения к религии, все же находят свое исламское воплощение. В ответ на призыв Р.Кадырова на расширенном заседании правительства уделить особое внимание повышению культуры земледелия в республике, А.Шахидов разместил пост на своей странице в Инстаграм с соответствующими комментариями из истории ислама и словами Пророка Мухаммеда. Здесь он пообещал, что в целях пропаганды земледелия ТРК «Путь» запустит новые проекты [52].

Еще один неформальный лозунг окружения Рамзана Кадырова, который перерос в движение и идеологический проект республики - это «Ахмат-сила!». Как показывает текстовый анализ сообщений, этот лозунг также не лишен религиозной подоплеки. Его герой первый президент

\begin{abstract}
ЧР Ахмат Кадыров позиционируется как «ИСТИННЫЙ МУСУЛЬМАНСКИЙ ПРАВИТЕЛЬ» [44]. Кроме того, очень часто слоган «Ахмат - сила!» сопровождается «Аллаху Акбар!». Само понимание слогана вполне конкретно раскрывается в комментариях А. Шахидова: «Лозунг Ахмат-сила это значит, что путь, который начал Ахмат Хаджи Кадыров, основываясь на принципах исламского права, он сильный путь. Действительно, этим путем он спас чеченский народ от полной гибели, по воле Всевышнего Аллаха!» [49].
\end{abstract}

\section{Заключение}

Политическая элита ЧР давно осознала важность и ценность интерне_ресурса и социальных сетей, в частности, для консолидации и мобилизации своего избирателя, и активно вплетает религиозный фактор в общественно-политическую жизнь республики. Как показал анализ личных страниц политических и религиозных лидеров ЧР в социальных сетях, религиозный контент присутствует во всех типах визуальных и текстовых сообщений, а исламская тематика остается одной из значимых для ее руководства. Ислам стал неотъемлемой частью общественно-политических реалий сегодняшней Чечни. Риторика и внешний облик политических лидеров все больше напоминают язык и поведение их коллег из религиозных структур.

В сравнении с более ранними исследованиями о публикационной активности Р. Кадырова в социальных сетях [72], можно констатировать наметившиеся изменения в его подходах. Методологически происходит постепенное сращивание нерелигиозных тем с исламом, например, спорта и веры. Справедливо говорить об усилении религиозного аспекта в официальном политическом дискурсе, с конструированием «чеченского ислама», который негласно стал официальной идеологией республики. Статусные роли в региональном религиозно - политическом 
дискурсе распределены таким образом, что Р. Кадыров задает тон дискуссии и легитимирует своим примером тесную связь религиозного и политического, А. Шахидов обеспечивает идеологическое встраивание религиозного в национальную доктрину, а С. Межиев отвечает за текущие вопросы. При этом вполне очевидно, что ссылка на религиозный контекст носит инструменталистский характер и определяется политической конъюнктурой. Справедливо заметить, что процессы, наблюдаемые в Чечне, развиваются по образу и подобию аналогичных процессов федерального центра. Современное российское государство больше не возражает против частичной клерикализации субъектов, правда, ее рамки сильно подвижны в зависимости от региона.
Модель государственно-религиозных отношений применительно к ЧР, где мы наблюдаем гипертрофированное значение религиозного, позволяет говорить об усилении элементов теократического правления. Ислам становится главным мерилом общественно-политических процессов, иногда в обход действующего законодательства. Подобная ситуация не может не настораживать в обозримом будущем. Особое беспокойство вызывают нарастающая претензия на уникальность в исламском мире, высокая военизированность чеченской уммы, культ исламских героев с сильной антироссийской тематикой. Сами по себе эти проявления не столь опасны, но их синтез в условиях недостаточного образовательного капитала, неблагоприятных социополитических процессов может привести к неожиданным последствиям.

\section{Библиографический список}

1. Гаджимурадова 3.М., Курбанова Ж.Т., Шабанова Ш.Г. Религиозное самосознание молодежи Северного Кавказа в условиях современных социально-политических процессов (на материале исследования студенческой молодежи Дагестана и Чечни) // Известия Дагестанского государственного педагогического университета. Психолого-педагогические науки. - 2018. - Т. 12. № 1. - C. 5-11. DOI: 10.31161/1995-0659-2018-12-1-5-11

2. Информационное агентство «Грозный-информ». Р. Кадыров: Чечня разделена на восемь секторов для более качественного решения вопросов социально-экономического развития на местах. 15.08.2019 [Электронный ресурс] - URL: https://www.grozny-inform.ru/news/economic/111538/ (дата обращения: 25.06.2020).

3. Кадыров P. [Рамзан Кадыров]. (03.01.2020 20:46) Ассаламу алайкум! Сегодня чеченский народ...[Электронный ресурс] - URL: https:/vk.com/ramzan?w=wall279938622_461139 (дата обращения: 25.06.2020).

4. Кадыров P. [Рамзан Кадыров]. $\quad(08.02 .2020$ 23:35) Наши предки наставляли сыновей словами...[Электронный ресурс] - URL: https://vk.com/ramzan?w=wall279938622_466795 (дата обращения: 25.06.2020).

5. Кадыров P. [Рамзан Кадыров]. (08.04.2020 5:06) Ассаламу алайкум! Наступила Ночь Бараат [Электронный ресурс] - URL: https://vk.com/ramzan?w=wall279938622 481041 (дата обращения: 25.06.2020).

6. Кадыров Р. [Рамзан Кадыров]. (09.06.2020 12:41) Ассаламу алайкум! Воздавая хвалу Всевышнему Аллаху...[Электронный ресурс] - URL: https://vk.com/ramzan?w=wall279938622_497501 (дата обращения: 25.06.2020).

7. Кадыров P. [Рамзан Кадыров]. (10.06.2020 2:21) Дружба между немногословными мужчинами...[Электронный ресурс] - URL: https://vk.com/ramzan?w=wall279938622_497692 (дата обращения: 25.06.2020).

8. Кадыров Р. [Рамзан Кадыров]. (12.03.2020 1:24) Дорогие друзья! В среду провёл расширенное совещание...[Электронный pecypc] - URL: https://vk.com/ramzan?w=wall279938622_473461\&z= video279938622_456242788\%2F2239f28f2d2402fd0c\%2Fpl_post_279938622_473461 (дата обращения: 25.06.2020).

9. Кадыров Р. [Рамзан Кадыров]. (17.03.2020 23:33) Ассаламу алайкум! Я провел большое совещание...[Электронный ресурс] - URL: https://vk.com/ramzan?w=wall279938622_474462 (дата обращения: 25.06.2020).

10. Кадыров Р. [Рамзан Кадыров]. (19.01.2020 22:59) Мой юный друг, запомни! [Электронный ресурс] URL: https://vk.com/ramzan?w=wall279938622_464102 (дата обращения: 25.06.2020). 
11. Кадыров $\quad$ P. [Рамзан Кадыров]. (19.05.2020 22:37) Ассаламу алайкум! Оперативный штаб...[Электронный ресурс] - URL: https://vk.com/ramzan?z=photo279938622 457296416\%2Falbum279938622_00\%2Frev (дата обращения: 26.06.2020).

12. Кадыров Р. [Рамзан Кадыров]. (19.06.2020 3:21) Ассаламу алайкум! Хвала Аллаху, Господу Миров... [Электронный pecypc] - URL: https://vk.com/ramzan?w=wall279938622_ 499395\&z=photo279938622_457297610\%2Fwall279938622_499395 (дата обращения: 26.06.2020).

13. Кадыров $P$. [Рамзан Кадыров]. (19.06.2020 3:21) Ассаламу алайкум! Хвала Аллаху, Господу Миров, по воле которого я с дорогими БРАТЬЯМИ...[Электронный ресурс] URL: https://vk.com/ramzan?w=wall279938622_499395 (дата обращения: 25.06.2020).

14. Кадыров P. [Рамзан Кадыров]. (20.05.2020 0:00 ) Ассаламу алайкум! На последнюю декаду...[Электронный ресурс] - URL: https://vk.com/ramzan?w=wall279938622_492923 (дата обращения: 25.06.2020).

15. Кадыров Р. [Рамзан Кадыров]. (20.06.2020 2:37) Дорогие друзья! Страна готовится к предстоящему голосованию... [Электронный ресурс] - URL: https://vk.com/ramzan?w=wall279938622_499566 (дата обращения: 25.06.2020).

16. Кадыров Р. [Рамзан Кадыров]. (22.04.2020 6:28) В далёкой юности, когда старшие нам брили головы...[Электронный pecypc] - URL: https://vk.com/ramzan?w=wall279938622_484845 (дата обращения: 25.06.2020).

17. Кадыров P. [Рамзан Кадыров]. (28.05.2020 20:52) Ибн аль-Джаузи (да помилует его Аллах) рассказывает...[Электронный ресурс] - URL: https://vk.com/ramzan?w=wall279938622_494761 (дата обращения: 25.06.2020).

18. Кадыров Р. [Рамзан Кадыров]. (29.02.2020 23:51) Настоящий мужчина должен уметь постоять за себя...[Электронный ресурс] - URL: https://vk.com/ramzan?w=wall279938622_470828 (дата обращения: 25.06.2020).

19. Кадыров Р. [Рамзан Кадыров]. (30.05.2020 16:28) Говорят, что друзья познаются в беде... [Электронный pecypc] - URL: https://vk.com/ramzan?w=wall279938622_495167 (дата обращения: 25.06.2020).

20. Кадыров P. [Рамзан Кадыров]. (30.05.2020 2:00) Tüm değerli KARDEŞLERİMİ...[Электронный pecypc] - URL: https://vk.com/ramzan?w=wall279938622_495065 (дата обращения: 25.06.2020).

21. Кадыров P.A. [Электронный pecypc] - URL̄: https://fedpress.ru/person/1638123 (дата обращения: 12.06.2020).

22. Кастельс M. Власть коммуникации [Текст] : учеб. пособие / М. Кастельс ; пер. с англ. Н.М. Тылевич ; под науч. ред. А.И. Черных ; Нац. исслед. ун-т «Высшая школа экономики». - М. : Изд. дом Высшей школы экономики, 2016.

23. Костецкий C., Первышева E. «Если надо, мы вернемся». Чеченцы устроили беспорядки во Франции. Почему они не понесли за это наказание? 18.06.2020 [Электронный ресурс] URL: https://lenta.ru/articles/2020/06/18/chechen_france (дата обращения: 22.06.2020).

24. Межиев C. [«Шейх Салахь-Хаджи Межиев»] (01.01.2020 02:02) Уважаемые братья и сестры!... [Электронный pecypc] - URL: https://t.me/salah_mezhiev/139 (дата обращения: 25.06.2020).

25. Межиев C. [«Шейх Салахь-Хаджи Межиев»] (01.04.2020 01:01) Чеченский народ...[Электронный pecypc] - URL: https://t.me/salah_mezhiev/575 (дата обращения: 25.06.2020).

26. Межиев C. [«Шейх Салахь-Хаджи Межиев»] (01.06.2020 02:21) Когда-то Посланник Аллаха...[Электронный pecypc] - URL: https://t.me/salah_mezhiev/865 (дата обращения: 25.06.2020).

27. Межиев C. [«Шейх Салахь-Хаджи Межиев»] (13.01.2020 19:43) Советник Главы Чеченской Республики...[Электронный ресурс] - URL: https:/t.me/salah_mezhiev/234 (дата обращения: 25.06.2020).

28. Межиев C. [«Шейх Салахь-Хаджи Межиев»] (13.02.2020 13:41) Самое ценное...[Электронный pecypc] - URL: https://t.me/salah_mezhiev/392 (дата обращения: 25.06.2020).

29. Межиев C. [«Шейх Салахь-Хаджи Межиев»] (21.01.2020 13:24) Вращение земли - сокрушительный удар по ваххабитской акыде! [Электронный ресурс] - URL: https://t.me/salah_mezhiev/280 (дата обращения: 25.06.2020).

30. Межиев C. [«Шейх Салахь-Хаджи Межиев»] (23.03.2020 03:40) На протяжении истории....[Электронный ресурс] - URL: https://t.me/salah_mezhiev/422 (дата обращения: 25.06.2020).

31. Межиев C. [«Шейх Салахь-Хаджи Межиев»] (24.01.2020 10:29) Пятничный (джума) намаз...[Электронный ресурс] - URL: https://t.me/salah_mezhiev/300 (дата обращения: 25.06.2020).

32. Межиев $C$. [«Шейх Салахь-Хаджи Межиев»] (29.06.2020 17:32) Советник Главы ЧР...[Электронный ресурс] - URL: https://t.me/salah_mezhiev/946 (дата обращения: 25.06.2020).

33. О бренде Firdaws [Электронный pecypc] - URL: https://firdaws-official.ru/ (дата обращения: 25.06.2020). 
34. Ситников A.B., Романов М.B., Одаев T.X. Религиозность в Чеченской Республике и ее влияние на социальные институты и институты власти //Мониторинг общественного мнения: Экономические и социальные перемены. - 2019. - № 2. - С. 157-183.

35. Фахрутдинов P. Чеченцы против «Магриба»: во Франции разгорается конфликт. 16.06.2020[Электронный pecypc] - URL: https://www.gazeta.ru/social/2020/06/15/13119049.shtml (дата обращения: 22.06.2020).

36. Хучиев M. [khuchiev_mm] (23.06.2020) Дорогие друзья! Сегодня в рамках исполнения... [Электронный pecypc] - URL: https:/www.instagram.com/p/CBx-RTbBDyV/ (дата обращения: 25.06.2020).

37. Шахидов A. [adam_shakhidov]. (02.03.2020) Слова защитника Ислама [Электронный ресурс] URL: https://www.instagram.com/p/B9PMM8WAhC9/ (дата обращения: 25.06.2020).

38. Шахидов A. [adam_shakhidov]. (03.06.2020) Служитель Священного Корана, Защитник пречистой Сунны Пророка ...[ЭЛектронный ресурс] - URL: https://www.instagram.com/p/CA-mOmvAZ3X/ (дата обращения: 25.06.2020).

39. Шахидов A. [adam_shakhidov]. (04.06.2020) Не оставить ни одну мечту великого...[Электронный pecypc] - URL: https://www.instagram.com/p/CBAy2oqgQcI/ (дата обращения: 25.06.2020).

40. Шахидов A. [adam_shakhidov]. (08.06.2020) Посланник Аллаха сказал ...[Электронный ресурс] URL: https://www.instagram.com/p/CBLtSHUAEkx/ (дата обращения: 25.06.2020).

41. Шахидов A. [adam_shakhidov]. (08.06.2020) Репост @dzhabrailusmaev. Телодвижения при поминании Аллаха [Электронный ресурс] - URL: https://www.instagram.com/p/CBKxAxIAVSD/ (дата обращения: 25.06.2020).

42. Шахидов A. [adam_shakhidov]. (09.06.2020) О верующий в АЛЛАХА чеченский народ...[Электронный pecypc] - URL: https://www.instagram.com/p/CBNIg9hAlRT/ (дата обращения: 25.06.2020).

43. Шахидов А. [adam_shakhidov]. (10.06.2020) Всевышний АЛЛАХ сказал... [Электронный ресурс] URL: https://www.instagram.com/p/CBOLOhUgZoi/ (дата обращения: 25.06.2020).

44. Шахидов A. [adam_shakhidov]. (13.01.2020) Спаситель народа по воле Аллах1а !!!... [Электронный pecypc] - URL: https://www.instagram.com/p/B7QzVOPAklC/ (дата обращения: 25.06.2020).

45. Шахидов А. [adam_shakhidov]. (13.06.2020) Мнение о служителе Корана Рамзане-Хаджи Кадырове Ясира аль-Хусейна... [Электронный ресурс] - URL: https://www.instagram.com/p/CBXg5W9Aai-/ (дата обращения: 25.06.2020).

46. Шахидов А. [adam_shakhidov]. (14.03.2020) Точность дело тонкое! Ахмат-Сила Аллах1у Акбар!!! [Электронный ресурс] - URL: https://www.instagram.com/p/B9r277hg4mb/ (дата обращения:: 25.06.2020).

47. Шахидов A. [adam_shakhidov]. (15.04.2020) Читайте Коран, Салаваты... [Электронный ресурс] URL: https://www.instagram.com/p/B-_2yf_gd52/ (дата обращения:: 25.06.2020).

48. Шахидов A. [adam_shakhidov]. (15.06.2020) Репост @kadyrov_za_islam. Взгляд всего исламского мира... [Электронный ресурс] - URL: https://www.instagram.com/p/CBa_- 7d4AKmb/ (дата обращения: 25.06.2020).

49. Шахидов A. [adam_shakhidov]. (17.03.2020) Что значит Ахмат-Сила? [Электронный ресурс] URL: https://www.instagram.com/p/B91wgD5gkPY/ (дата обращения: 25.06.2020).

50. Шахидов A. [adam_shakhidov]. (18.02.2020) Ассаламу Алейкум, уважаемые братья и сестры. Социальные сети один из главных... [Электронный ресурс] URL: https://www.instagram.com/p/B8tSTD9ALFb/ (дата обращения: 25.06.2020).

51. Шахидов A. [adam_shakhidov]. (18.02.2020) Согласны с Шейхом? [Электронный ресурс] URL: https://www.instagram.com/p/B8tpLRuA7Ha/ (дата обращения: 25.06.2020).

52. Шахидов A. [adam_shakhidov]. (18.03.2020) Дорогие друзья! Принял участие в расширенном совещании... [Электронный ресурс] - URL: https:/www.instagram.com/p/B92WJDFopto/ (дата обращения: 25.06.2020).

53. Шахидов A. [adam_shakhidov]. (18.05.2020) Битва при Айн-Джалуте [Электронный ресурс] URL: https://www.instagram.com/p/CAU3zwzAa2X/ (дата обращения: 25.06.2020).

54. Шахидов A. [adam_shakhidov]. (19.04.2020) Хастам бу хьуна йа Аллах... [Электронный ресурс] URL: https://www.instagram.com/p/B_KDctUAJqv/ (дата обращения: 25.06.2020).

55. Шахидов A. [adam_shakhidov]. (22.02.2020) Интересный вопрос!!! [Электронный ресурс] URL: https://www.instagram.com/p/B83L6nmAeQq/ (дата обращения: 25.06.2020).

56. Шахидов A. [adam_shakhidov]. (22.05.2020) Когда каждый из нас не работник, не сотрудник... [Электронный pecypc] - URL: https:/www.instagram.com/p/CAgBUb4AHFm/ (дата обращения: 25.06.2020).

57. Шахидов A. [adam_shakhidov]. (22.05.2020) Хвала Аллаху за нашего Льва [Электронный ресурс] URL: https://www.instagram.com/p/CAfqQ7tATaA/ (дата обращения: 25.06.2020).

58. Шахидов A. [adam_shakhidov]. (22.06.2020) По поручению Главы ЧР, Служителя Священного Корана Рамзана-Хаджи Кадырова... [Электронный URL: https://www.instagram.com/p/CBqTiQhAUP9/ (дата обращения: 25.06.2020). 
59. Шахидов A. [adam_shakhidov]. (22.06.2020) Франция нуждается в чеченцах!!! [Электронный ресурс] URL: https://www.instagram.com/p/CBs6tCBAsJc/ (дата обращения: 25.06.2020).

60. Шахидов A. [adam_shakhidov]. (22.06.2020) Франция нуждается в чеченцах!!! [Электронный ресурс] URL: https://www.instagram.com/p/CBs6tCBAsJc/ (дата обращения: 23.06.2020).

61. Шахидов А. [adam_shakhidov]. (23.02.2020) Ассаламу Алайкум, уважаемые братья и сестры! Сегодня 76 лет со дня трагической даты... [Электронный ресурс] URL: https://www.instagram.com/p/B859iN3gciE/ (дата обращения: 25.06.2020).

62. Шахидов A. [adam_shakhidov]. (24.01.2020) Жизнь - это борьба [Электронный ресурс] URL: https://www.instagram.com/p/B7tCz8EgQSG/ (дата обращения: 25.06.2020).

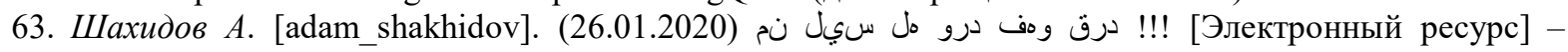
URL: https://www.instagram.com/p/B7yIdtJARc6/ (дата обращения: 25.06.2020).

64. Шахидов А. [adam_shakhidov]. (26.02.2020) Дала декъалвойла Хьо Мохьмад, Дала диканца дуккха вахавойла,оцу сийлахьчу меттигашкахь Дала цхьана гулдойла вай кеста йолчу заманахь [Электронный pecypc] - URL: https://www.instagram.com/p/B9AcBtBgKM0/ (дата обращения: 26.06.2020).

65. Шахидов A. [adam_shakhidov]. (28.02.2020) Свет Корана сияет в доме Служителя Корана [Электронный ресурc] - URL: https://www.instagram.com/p/B9GmGx8AFmI/ (дата обращения: 25.06.2020).

66. Шахидов A. [adam_shakhidov]. (28.02.2020) Хвала Аллах1у... [Электронный ресурс] URL: https://www.instagram.com/p/B9HW0nJAjy_/ (дата обращения: 25.06.2020).

67. Шахидов A. [adam_shakhidov]. (28.05.2020) Кто не понял тот поймёт [Электронный ресурс] URL: https://www.instagram.com/p/CAuQMIMAd6o/ (дата обращения: 25.06.2020).

68. Шахидов A. [adam_shakhidov]. (29.05.2020) Наши братья по вере порой любимее... [Электронный pecypc] - URL: https://www.instagram.com/p/CAv16FAgJIg/ (дата обращения: 25.06.2020).

69. Шахидов А. [adam_shakhidov]. (31.03.2020) Мои дорогие подписчики, просьба подписаться на эту страницу... [Электронный ресурс] - URL: https://www.instagram.com/p/CA0zOrigh2T/ (дата обращения: 25.06.2020).

70. Шахидов A. [adam_shakhidov]. Репост @kadyrov_za_islam. Вот поэтому мы молимся за нашего правителя Рамзана Кадырова...[Электронный ресурс]

URL: https://www.instagram.com/p/CBBFtbMA2ti/ (04.06.2020) (дата обращения: 25.06.2020).

71. Шахидов A. [adam_shakhidov]. Репост @kadyrov_za_islam. Смелость - это драгоценное...[Электронный pecypc] - URL: https://www.instagram.com/p/CA_AmOMgy6Z/ (04.06.2020) (дата обращения: 25.06.2020).

72. Avedissian K. Clerics, weightlifters, and politicians: Ramzan Kadyrov's Instagram as an official project of Chechen memory and identity production, Caucasus Survey. - 2016. - Vol. 4. - № 1. - P. 20-43. DOI: $10.1080 / 23761199.2015 .1119998$.

\title{
THE RELIGIOUS FACTOR IN REGIONAL IDENTITY POLICY: THE SELF- PRESENTATION OF CHECHEN LEADERS IN THE SOCIAL NETWORKS
}

\author{
A.V. Mikhaleva \\ Perm Federal Research Center UB RAS
}

Contemporary network society with the exclusive role of Internet communications is significantly changing all spheres of life, opening up additional opportunities for manipulating public consciousness through virtual channels. The article looks into the religious aspect of self-presentation of several leaders of the Chechen Republic in the social networks and considers how the "religious factor" is actualized on the Internet pages of the political and religious elite of the republic. The social political analysis of the views and attitudes of elite groups allows us to determine the development vectors of the regional community and to predict emerging problems, the main characteristics and elements of which are reflected on social network pages. The article presents the results of a sociological study of Internet activity of the Chechen elite on the VKontakte, Instagram and Telegram pages. The study was based on network analysis, that is, a noncontact method of digital sociology, taking into account the normative, visual and substantial aspects of the presentation of the studied objects. The following political and religious leaders of the Chechen Republic were chosen: Ramzan Kadyrov, the Head of the Chechen Republic, Muslim Khuchiev, the Chairman of the Chechen Government, Adam Shakhidov, the Advisor to the leader of the Chechen 
Republic on religious issues, and Salah Mezhiev, Mufti of the Chechen Republic. The analysis of their publication activity and textual content of comments was carried out, which allowed us to identify the key strategies for incorporating religious resource in the regional identity policy. As a result of the study, the high significance of the religious resource for the ideological substantiation of political actions of the regional elite was revealed. Moreover, the reference to the religious context is instrumentalistic and is determined by the political conjuncture. In conclusion, the most problematic points of religious discourse of the Chechen leaders are indicated.

Keywords: Islam, Islam, institutionalization, identity policy, social networks, Kadyrov, Khuchiev, Shakhidov, Mezhiev.

\section{Сведения об авторе}

Михалева Альбина Викторовна, кандидат политических наук, старший научный сотрудник Пермский федеральный исследовательский центр УрО РАН (ПФИЦ УрО РАН), 614990, г. Пермь, ул. Ленина, 13a; e-mail: mialba@yandex.ru 